Riquet M, Foucault C, Cazes A, Mitry E, Dujon A, Le Pimpec Barthes F, Medioni J, Rougier P (2010) Pulmonary resection for metastases of colorectal adenocarcinoma. Ann Thorac Surg 89(2): 375-380.

Rooney KP, McAleese J, Crockett C, Harney J, Eakin RL, Young VA, Dunn MA, Johnston RE, Hanna GG (2015) The impact of colleague peer review on the radiotherapy treatment planning process in the radical treatment of lung cancer. Clin Oncol ( $R$ Coll Radiol) 27(9): 514-580.

Treasure T, Monson K, Fiorentino F, Russell C (2014) The CEA second-look trial: a randomised controlled trial of carcinoembryonic antigen prompted reoperation for recurrent colorectal cancer. BMJ Open 4(5): e004385.

*Correspondence: Professor P-E Falcoz; E-mail: pierre-emmanuel.falcoz@wanadoo.fr Published online 15 September 2015

(c) 2015 Cancer Research UK. All rights reserved 0007-0920/15

http://creativecommons.org/licenses/by-nc-sa/4.0/

\title{
Is it the creatine or the anabolic androgenic steroids? Need for assessing the steroids role in testicular cancer
}

Patrick Cazorla-Saravia ${ }^{*}, 1$ and Reneé Pereyra-Elías ${ }^{1}$

${ }^{1}$ MD Escuela de medicina, Universidad Peruana de Ciencias Aplicadas,

Sir,

We have read with considerable interest the case-control study by Li et al. (2015), in which muscle building supplement (MBS) use was found as an associated factor with testicular germ cell cancer. It is important to remark that the association remained statistically significant even after controlling for important potential confounders. However, we consider that there is one nonassessed variable that might be relevant in the multi-causal model for testicular cancer.

Previous research shows that the frequency of anabolic androgenic steroid (AAS) use within practitioners of recreational physical activity can be as high as 30 (Abrahin et al, 2014) to 50\% (Dodge et al, 2011). Therefore, there is high probability of concomitant AAS and MBS use. In addition, AASs have been associated with the development of some types of cancer. Nandrolone and stanozolol, two of the most used AASs, have proven to enhance Leydig cell proliferation, increasing the risk of tumour development in rats (Chimento et al, 2012). There is also suggestive evidence that involves AAS in Leydig cell tumour growth in humans (Belli et al, 2013). In this scenario, AAS could be playing an undetected role in malignancy development instead of or in conjunction with MBS.

Moreover, two recently published articles detected the presence of AAS in products marketed as dietary supplements (Abbate et al, 2014; Odoardi et al, 2015). Thus, the MBS consumed by Li's study participants could have been contaminated with AAS. This highly probable mix of substances does not allow us to convincingly blame one specific compound.

In summary, Li's results provide valuable information suggestive of MBS use as a potential risk factor for testicular cancer. However, future research

Calle El Paraíso 170, La Molina, Lima 12, Peru

considering the potential AAS effect should be carried out in order to clarify the real influence of this substance.

\section{REFERENCES}

Abbate V, Kicman AT, Evans-Brown M, McVeigh J, Cowan DA, Wilson C, Coles SJ, Walker CJ (2014) Anabolic steroids detected in bodybuilding dietary supplements - a significant risk to public health. Drug Test Anal 7: 609-618.

Abrahin OS, Sousa EC, Santos AM (2014) Prevalence of the use of anabolicandrogenic steroids in Brazil: a systematic review. Subst Use Misuse 49(9): $1156-1162$.

Belli S, Guidi A, Simoni M, Carani C, Granata AR (2013) Leydig cell tumor in an anabolic steroid abuser. J Endocrinol Invest 36(10): 913.

Chimento A, Sirianni R, Zolea, De Luca A, Lanzino M, Catalano S, Ando S, Pezzi V (2012) Nandrolone and stanozolol induce Leydig cell tumor proliferation through an estrogen-dependent mechanism involving IGF-I system. J Cell Physiol 227: 2079-2088.

Dodge T, Hoagland MF (2011) The use of anabolic androgenic steroids and polypharmacy: a review of the literature. Drug Alcohol Depend 114: $100-109$

Li N, Hauser R, Holford T, Zhu Y, Zhang Y, Bassig BA, Honig S, Chen C, Boyle P, Dai M, Schwartz SM, Morey P, Sayward H, Hu Z, Shen H, Gomery P, Zheng T (2015) Muscle-building supplement use and increased risk of testicular germ cell cancer in men from Connecticut and Massachusetts. Br J Cancer 112: $1247-1250$.

Odoardi S, Castrignanò E, Martello S, Chiarotti M, Strano-Rossi S (2015) Determination of anabolic agents in dietary supplements by liquid chromatography-high-resolution mass spectrometry. Food Addit Contam Part A Chem Anal Control Expo Risk Assess 32(5): 635-647.

*Correspondence: Dr P Cazorla-Saravia; E-mail: patrickcazorla@hotmail.com Published online 11 August 2015

(c) 2015 Cancer Research UK. All rights reserved 0007-0920/15
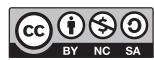

http://creativecommons.org/licenses/by-nc-sa/4.0/
$\mathrm{BJC}$ OPEN 1

\section{Comment on 'Impact of intra-arterial chemotherapy including internal carotid artery for advanced paranasal sinus cancers involving the skull base'}

Paolo Bossi ${ }^{*, 1}$, Ester Orlandi ${ }^{1}$ and Lisa Licitra ${ }^{1}$

${ }^{1}$ Fondazione IRCCS Istituto Nazionale dei Tumori, Milan, Head and Neck Medical Oncology Unit, Via Venezian, 1, Milano, Italy

Sir,

We read with great interest the paper by Yokoyama J et al, 2014. 'Impact of intra-arterial chemotherapy including internal carotid artery for advanced paranasal sinus cancers involving the skull base'.

There are some major issues that in our opinion strongly limit the possibility of drawing any conclusions.

The paper presents the experience of intra-arterial cisplatin chemotherapy (46 patients) compared with historical controls (11 patients) not employing infusion of the internal carotid artery, presenting survival data of both series. However, it is difficult to make any comparison, as there is no histology specification about the treated cancers, which can have a significant prognostic impact in paranasal sinus cancers (Ganly et al, 2005; Llorente et al, 2014).

The inclusion criteria of this study have not been specified. For example, it is unclear how many patients were considered and how many were eligible; this would help in understanding the feasibility of this approach. How many cases were judged as unresectable? This is the group of patients having the worst prognosis, which indeed would benefit from alternative approaches such as intra-arterial chemotherapy (Hoppe et al, 2008); on the other hand, when a paranasal sinus cancer is resectable, surgery represents the standard treatment followed by radiotherapy (Dulguerov and Allal, 2006).

Moreover, it is very unclear if the adopted therapeutic strategy was the same for all cases. The authors stated that 29 of 32 patients with invasion of orbital apex were treated with preservation of the orbital contents, probably suggesting that radiotherapy was given in a preoperative setting.

Therefore, it is vital to clarify whether radiotherapy was administered with radical intent or preoperatively. The reported total dose of $60 \mathrm{~Gy}$ to tumour and nodal metastasis with standard fractionation could hardly be curative if definitive treatment was planned. In fact, receiving a total dose of at least $65 \mathrm{~Gy}$ is known to be a significant prognostic factor for both tumour local control and overall survival at least in unresectable paranasal sinus cancers (Hoppe et al, 2008). Furthermore, no specific data on surgery has been provided in the paper.

In the statistical part, larynx-preservation rates are calculated and compared between the two groups. In our experience larynx preservation is 